\title{
The Effectiveness of In-Service Training Program: The Case of Teachers' Working Culture and Program Development Program Indonesia
}

\author{
Ade Ahmad Kopsasih*, Bedjo Sujanto, and Wibowo
}

\begin{abstract}
Post graduate program, Jakarta State University, Corresponding Author, Ade Ahmad Kopsasih
\end{abstract}
\begin{abstract}
Professional management of an educational program brings a positive impact on educational outcomes. Therefore, teachers are important pillars in improving learning through professional management of education. The Teacher Work Culture Development Center in Banten Province organizes in-service teacher training as an effort to enhance teacher competences. However, the effectiveness of the in-service training program needs to be systematically studied. This study uses a quantitative approach supported by the qualitative approach. 200 samples were randomly selected from the population consisting of 650participants. Findings indicate that the effectiveness of the in-service training program implemented to enhance teacher competence is quite good, especially in relation to the management of learning. The training process focuses on the pedagogical condition and performance; technical condition and performance; sociological condition and performance; the participants' activity as well as the psychological and social condition of the learning activity in the training. Focus on the above yields effectiveness. After training, participants are expected to pass on what they acquired during the training to other teachers.
\end{abstract}

Keywords: Training Effectiveness, In-On Service Training, P2BKG (Teacher Work Culture Development Program)

\section{Introduction}

Education has a crucial role in improving the human source quality. Education with high quality on its turn has forward linkage and backward linkage. First, good education is the prerequisite to create the advance, modern, dignified, and prosperous life of a nation. Second, good education will depend on the education and educator with high quality; that is to say, the good education relies on the professional, prosperous, and dignified teacher and administrative staff. Hence, the educator with high quality is the absolute prerequisite to make good educational system and practice.

All countries in the world keep attempting to develop their policy that supports the high-quality teacher development. The United States describes the ideal condition of the educational function in building the 21 st century society. Building the knowledge-based society in the 21 st century focuses on three main performances that should be created through education. They are, the performance of life and career, the performance of studying and making innovation, and the performance of mastering information, media, as well as the information technology and communication. The teacher's role tends to be seen as the facilitator, manager, guide, and friend. This description can be read in the recommendation result team Partnership for 21 Century Skills as visualized in figure 1 below: 


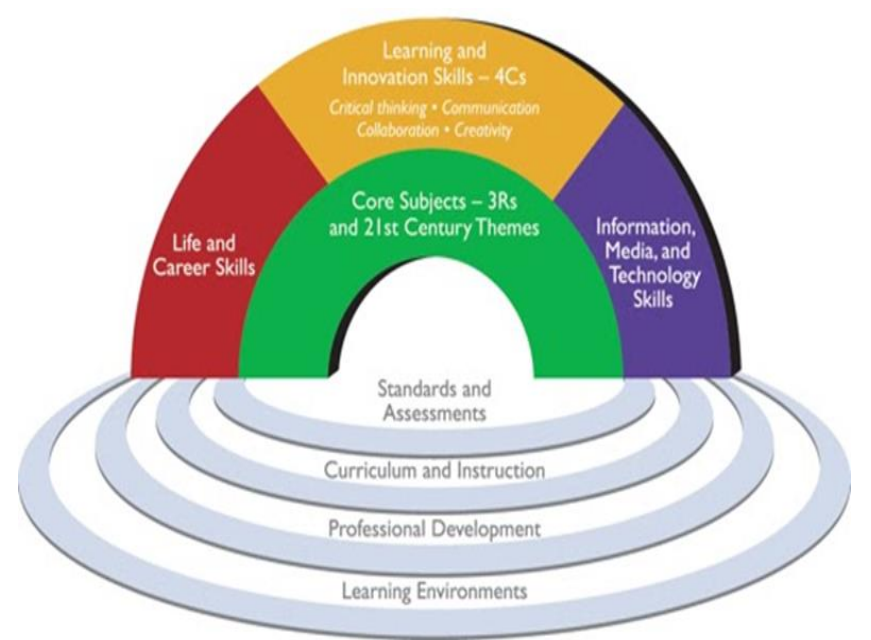

Figure 1: The criteria of the 21st century society building

The goal of the recommendation above is to develop skills as stated in the four educational pillars according to UNESCO. The pillars cover the skill of learning to know/learn, learning to do, learning to be, and learning to live together; or Partnership for 21 Century Skills. (Thijs, et al., 2011); (Ycc, 1989); (Chapman and Aspin, 1992); (Chukyoshin, 1996)

The teacher is seen to be the most important element to observe and consider. One of the things that can be observed from a teacher is the work culture. Work culture refers to the values of someone's habit that can determine his quality in a workplace. Teacher work culture can be realized through his technical responsibility and moral responsibility.

However, the educational development in Indonesia cannot be separated from problems. According to Sukmadinata (cited in Musfah,2011), the educational development problems result from the lack of the learning facilities; a teacher is said to be one of the causes. First, teacher works less seriously; second, the professional skills of the teacher is seen low due to the low educational qualification and teacher competence as well as the teacher's low commitment and motivation to achieve the higher education. The education quality refers to the process quality and the outcome quality. Thus, the periodic improvement of the teacher competence is important (Hardjana, 2009); (Dessler, 1997);
(Imron, 1995); (Hasibuan, 2012); (Usman and Uzer, 1950).

Banten Province Government attempts to improve teachers' professionalism and prosperity by doing strategic efforts such as providing facilities and guidance to improve the qualification, competence, prosperity as well as providing legal protection and teaching profession protection. The total of teachers in Banten Province based on the report of The Indonesian Teachers Association (IGI) or called PGRI are 85,190 teachers; 77,747 out of 85,190 have Bachelors' degree where 37.691 have been certified and 47,499 have not.

The Indonesian Teachers Association (IGI) of Banten Province provides the in-on service training program as the effort to improve the teacher competence. Yet, a systematic study on the effectiveness of the in-on service training needs to be conducted. This is in line with the phenomenon describing that many trainings to develop the teacher competence have been conducted, yet the effectiveness of the training or the objective outcome of the training needs to be further confirmed. A few training programs teach the learning and teaching vision to the teachers. If most of the trainings still need to be evaluated, the inefficiency of time, work, and fund is predicted to exist. It shall be anticipated because all teachers need education and professional training so that they can bear their responsibility as a teacher. (Hardjana, 2009); (Hasibuan., 2012); (Anwar, 2014)

This study discovers that the provided training has a quite good outcome. The training program has been conducted effectively, in terms of the time, material, resource performance, media use, and the training condition which simultaneously gives a strong impact on the outcome: performance and pedagogical performance; performance and technical performance; performance and sociological performance; the participant's activity during the training as well as the technical performance; the participant's activity during the training as well as the psychological performance and the social learning during the training. 


\section{Research Method}

This study is conducted in four regencies/cities including the regency of Pandeglang, the regency of Tangerang, the city of south Tangerang, and the city of Cilegon. This study employs a quantitative approach supported by the qualitative data (Moleong, 2003). The data are collected through questionnaire, interview, document, and participant observation. 200 samples of this study mostly consist of teachers in Banten Province who have experience to join the training in a teacher work culture development center or known as P2BKG. The samples are randomly selected considering the proportion needed. This study employs a type of the evaluation research with the expectation that this study will be able to give the useful input for the future training.

\section{Results of the Study}

\section{In-on service training program of P2BKG}

P2BKG tries to accomodate various activities of teachers. One of them is the training of teacher competence improvement. The result of the study shows that $\mathrm{P} 2 \mathrm{BKG}$ is standardized well in developing the programs. These include the standards of program, organization, development, facilities and infrastructure, human resource, financing, quality assurance, program proposal, and financing proposal.
In-on service training applies participative approach, so the participants should be active during the program, involved in discussion and conclusion. The competence that will be improved in this study is pedagogical and professional comptence. This program employs methods of brainstorming, discussion, work in group, problem solving, and presentation of the work. In the first stage, in1, the participants have some classes in advance to have direction and guidance from the trainer regarding the training materials and preparation of learning media for the next step. In the second stage, on-training, the participants learn independently by doing the learning activities in their respective school. In the last stage 2, the participants collect their paper as the result of independent homework and it will be discussed with the trainer and other participants to be reflected.

\section{The efectivity of program input}

The result of the study related to training input shows that $58 \%$ of respondents give the good responses to the whole programs held while $42 \%$ of them provide the very good responses. It shows that the participants are enthusiastic to follow the training. Meanwhile, to measure the participants' improvement, it uses two aspects which are antecendent and transaction with these following results.

Table 1: Distribution Percentage of Participant's Responses per Component

\begin{tabular}{|l|l|c|c|c|c|c|}
\hline \multirow{2}{*}{ Aspect } & Component & \multicolumn{5}{|c|}{ Response (\%) } \\
\cline { 3 - 7 } & & SK & K & C & B & SB \\
\hline \multirow{3}{*}{ Antecedent } & The participants' characteristics & 0 & 0 & 6 & 52 & 42 \\
& Learning motivation & 0 & 0 & 23 & 68 & 9 \\
\cline { 2 - 7 } & Preparation of training lesson & 0 & 0 & 33 & 62 & 5 \\
\hline \multirow{2}{*}{ Transaction } & Training lesson & 0 & 0 & 24 & 51 & 25 \\
\cline { 2 - 7 } & Participants' participation & 0 & 0 & 21 & 50 & 29 \\
\hline
\end{tabular}

Table 1 above demonstrates that the participants give good, even very good scores on each component of training input. Some considerations for program developer are to do innovation in the simulation of learning practice such as peer teaching substituted with lesson study in the school. The participants are less interested in simulation practice because the trainer and the core teachers are not ready in developing the lesson.

\section{The effectivity in 1 program}

The training process in this study is measured with pedagogical, psychological, and sociological performances as well as sociological and psychological participations. Through t-student 
statistics test, the result of regression lines siginify some indicators that should be concerned for the future training which are 1) a trainer needs an ability to improve the class performance, 2) diversity of training measurement is needed, 3) the trainer should deepen and extend the knowledge in discussing the cases of learning issues. The calculation result in the effectivity of training process indicates that most of subvariable have positive scores, so that the measurement in each indicatior will be valid.

\section{The effectivity of in 1 and in 2 training results}

The improvement from in 1 to in 2 is measured by four sub-components which are the pedagogical, technical, psychological, and sosiological perfomances of of training lesson. First, performance of pedagogical learning in in-on service training of teachers competence improves $0.9 \%$. Despite the low improvement, it can be understandable since the this improvement is considered very low but understandable

The improvement could be said low-yet understanable-due to its existance in the category "very good". This result signifies that there is significant improvement in the atmosphere and performance of pedagogical learning of in-on service training that supports the improvement of teacher professionalism. Second, there is improvement from in1 to in 2 in the atmosphere and the perfomance of technical learning in in-on service training that increases by $41 \%$ on average. This could be considered high, meaning that the result of in-on service training improves the teacher professionalism. Third, there is improvement from in1 to in 2 in the atmosphere and performance of psychological leaning in in-on service training that increases by $66 \%$. This improvement is considered high.
On the other hand, sociological performance of teacher competence from in 1 to in 2 decreases by $4 \%$ on average. This does not entirely decrease. The decrease is related to the trainer's availability to spare the time to have consultation outside the class.

\section{The comparison of training result per region}

The test is conducted through scatter plot from QQ, fit test of distribution through the KolmogorovSmirnov Goodness of Fit Test, and then t-test to find the comparison of the training between in 1 and in2. The test is conducted by comparing some regencies / cities. The calculation result mentions that the respondent score of in2 is significantly better than in1. It means that the process of in-on service training gives significant influence towards the competence of teacher professionalism.

The result of $\mathrm{F}$ calculation on the comparison of $\mathrm{N}$ Gain between regions is 3.507 that gives an opportunity implication of rejection of the null hypothesis of 0.018 . This probability value is smaller than $0.05(\square)$. This means that there are at least two regions that have a significantly different mean score of gain. To discover it, an advanced anova test is employed. The homogeneity test of variance between homogenous gain scores is shown in this following table.

Table 2: Test of Homogeneity of variances $N$ gain

\begin{tabular}{|l|c|c|c|}
\hline Levine Statistic & df1 & df2 & Sig. \\
\hline 1.347 & 3 & 97 & .264 \\
\hline
\end{tabular}

The result of table 2 above gives direction to the next anova test selection. The selected test is Tukey HSD test which is the advanced test in a homogeneous group of variance.

\section{Table 3: The advanced results of Anova test}

\section{Multiple Comparisons}

Dependent Variable: $\mathrm{N}$ gain

Tukey HSD

\begin{tabular}{|c|c|c|c|c|c|c|}
\hline $\begin{array}{c}(\mathrm{I}) \\
\text { Reg/ city }\end{array}$ & $\begin{array}{c}(\mathrm{J}) \\
\text { Reg/ city }\end{array}$ & $\begin{array}{c}\text { Mean Different (I- } \\
\mathrm{J})\end{array}$ & Std. Error & Sig. & \multicolumn{2}{|c|}{ 95\% Confidence Interval } \\
\cline { 6 - 7 } & 2 & $.09302^{*}$ & .03397 & & Lower Bound & Upper Bound \\
\hline 1 & 2 & .036 & .0042 & .1818 \\
\hline
\end{tabular}




\begin{tabular}{|c|c|c|c|c|c|c|}
\hline \multirow{3}{*}{2} & 3 & $.08416^{*}$ & .03129 & .041 & .0024 & .1660 \\
\cline { 2 - 6 } & 4 & .07126 & .03160 & .116 & -.0113 & .1539 \\
\hline \multirow{3}{*}{3} & 1 & $-.09302^{*}$ & .03397 & .036 & -.1818 & -.0042 \\
\cline { 2 - 7 } & 3 & -.00886 & .03423 & .994 & -.0983 & .0806 \\
\hline \multirow{3}{*}{3} & 4 & -.02176 & .03451 & .922 & -.1120 & .0685 \\
\cline { 2 - 7 } & 1 & $-.08416^{*}$ & .03129 & .041 & -.1660 & -.0024 \\
\cline { 2 - 7 } & 2 & .00886 & .03423 & .994 & -.0806 & .0983 \\
\hline \multirow{3}{*}{4} & 1 & -.01290 & .03188 & .977 & -.0962 & .0704 \\
\cline { 2 - 7 } & 2 & -.07126 & .03160 & .116 & -.1539 & .0113 \\
\cline { 2 - 7 } & 3 & .02176 & .03451 & .922 & -.0685 & .1120 \\
\hline
\end{tabular}

* The mean difference is significant at the 0.05 level.

The result in table 3 above shows that the different mean gain scores occur in group 1 and 2, Pandeglang Regency and Cilegon City. Then, the other mean gain scores that are different occur in group 1 and group 3, Pandeglang Regency and Tangerang Regency. Meanwhile, the other sets do not have significant difference.

\section{Discussion}

P2BKG tries to accommodate various activities of teachers including a meeting, model development, research design, group discussion, workshop, training, or the others in order to develop their competencies. Those are conducted to advance the teachers' knowledge, skill, and behavior according to the demands of competence and professionalism. (Hasibuan, 2012); (Sudaryanto, 2016); (Clawson and Haskins, 2006)

In-on service training applies participative approach focusing on the andragogy scientific approach in group. This approach is chosen to enable the participants to be active during the training process to achieve optimal results. Participants should be active throughout the activities and engage in discussion and conclusions. This activity applies brainstorming methods, exposure, consultative / clinical discussions, work in group, problem solving, presentation of work, peer teaching, and real teaching.

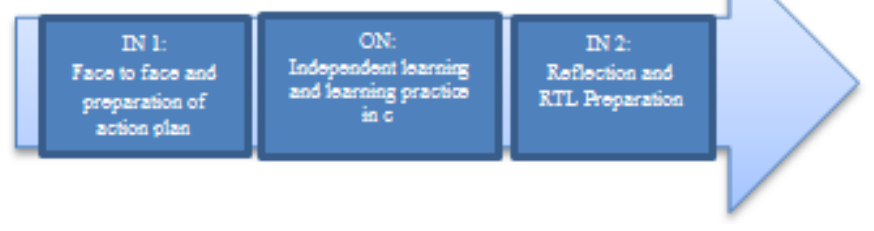

Figure 2: In-on service training stage

Through this cycle, the participants think that there are a lot of things obtained from the training activities, thus, those influence their competencies in content, explanation, and discussion with the trainer and core teacher, as well as pedagogical content knowledge (PCK) through problem-based learning development, implementation, and reflection. Widodo (2017) conducted study on PCK whose the result reveals that PCK is very important in teaching practice for teacher. PCK enables teacher to develop lesson that does not facilitate students' reasoning. Therefore, the teachers will develop their potential to arrange the strategy of new learning that facilitates students' reasoning. (Appleton., 2006); (Baxter and Lederman, 1999); (Cochran, Deruiter and King, 1993); (Loughran, Berry and Mulhall, 2006)

Descriptive study on data processing about the characteristics of participants, trainer, facilities, and infrastructure provides information that participants who join this program include high school teachers and vocational school. Teachers who attend this program have diversity in teaching experiences, gender, rank and class, participation in various trainings, and competence. These are the triggers of cooperative learning strategy that will be implemented properly. This is as stated by 
Killen (1998) that in cooperative learning strategy, there must occur four things, namely external motivation, social cohesion, cognitive elaboration, and cognitive development. As the result, participants are assessed that the training which P2BKG has performed has benefited in improving their professional competence.

In P2BKG, participants / teachers and trainer try to explore the problems through self-reflection which has been done by the teachers during doing their duties. The participants are encouraged to disclose any problems experienced both in terms of curriculum content and pedagogic. The position of instructor / trainer in training has its own unique role. If related to the Schwarz's (2002) concept, the position of this core teacher is a facilitator in the training and the trainer is a facilitative consultant. The core teacher positions her/himself as a neutral person who delivers a learning content. Meanwhile, the presence of trainer is intended to support the exposure of teaching materials training. The trainer is the expert who will strengthen some practical solutions to some discussion issues.

This kind of learning is the characteristic of andragogy learning where the participants (teachers) are placed as learning sources. The lesson experienced by each teacher can be the source of discussion where the problem that occur can be overcome with its solution. Sudaryanto (2016) explains that the principles of andragogy learning include the value of benefits, experiencebasis, everyday-problems involvement, practical materials, need-basis, interesting issue to discuss, active participation, and cooperation. In outline, the training conducted by P2BKG has already covered those principles. Therefore, the participants are enthusiatic to join this training in order to improve their professional competence as a teacher. (Sudaryanto, 2016); (Clawson, and Haskins, 2006); (Hasibuan, 2012); (Fauzi, 2011)

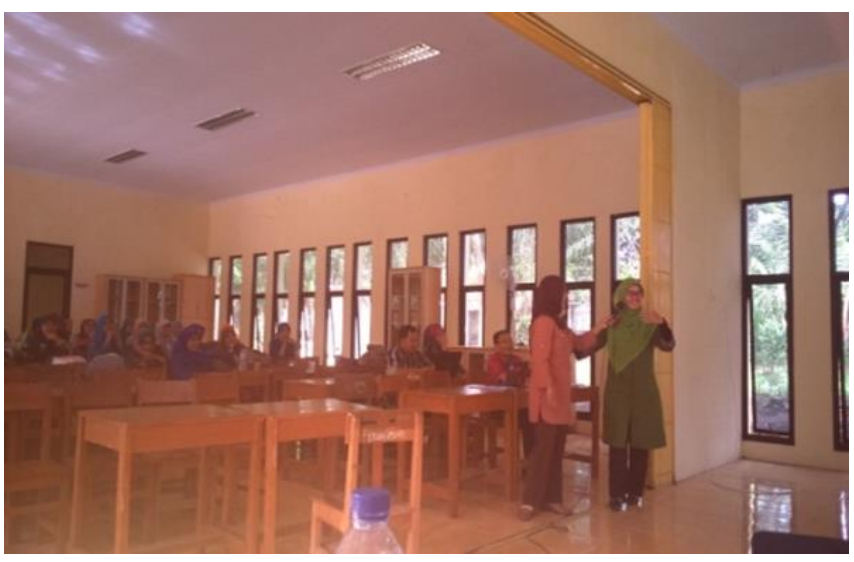

Figure 3: Presentation of group discussion result

Quality training does not only fulfill the input or output aspects but also the process aspects. (Aziz, 2015). To strengthen the findings of this study, the effectiveness of the training can also be reviewed based on the opinion of Tamim and Hermansjah (2002, p.35) who explain that the effectiveness of the training can be seen from the implementation of all training programs in accordance with 1) the time schedule, 2) the well arrangement of all activities in training with discipline, dedication, and ability, 3) efficiency in the use of available facilities and infrastructure, 4) the target goals for the training program. Quality training does not only fulfill the input or output aspects but also the aspects of the process.

The use of simulation practices in the learning process provides a reflection that the participants have already received the content and pedagogical knowledge, and develop a well-designed lesson plan. The use of the simulation method will make the participants experience a certain condition, so that it is expected to develop certain characteristics according to the participants' objectives. Thus, based on the simulation practice of learningg, then the indicator of learning as a result of the training process proposed by Gomes has been achieved. Furthermore, the assessment of the learning success can be seen from the participant's response to the indicator 'the liveliness of the participants in carrying out the structured tasks (paper, summaries, exercise questions, problem solving, etc.) provided by the trainer'. 
Training as an effort to develop and improve teachers' performance is basically a never-ending school requirement. According to the Ministry of National Education (DTK, 2008) teacher performance can be seen and measured based on competence specification / criteria that must be owned by every teacher. Related to the teacher performance, the manifestation of intended behavior is the activity of teachers in the learning process on how they plan the learning program, carry out learning activities, and assess learning outcomes. In this study, the teacher performance assessment is part of the problem formulation in the evaluation of the success of in-on service training of teacher competence improvement held by P2BKG Banten Province. (Masnun, 2014); (DTK, 2008); (Ditjen PMPTK, 2010); (Risnawatiririn, 2009); (Tjutju dan Suwatno, 2011).

In every subject, planning should always be created and mastered before the implementation of the lesson. In line with the opinion of Goh (2013), a competent teacher does not only master pedagogical skills and knowledge content but also the management of learning. Administrative matters related to learning need to be mastered in accordance with the latest policy.

The results of research shows that on the performance of teachers who participate in the training of lesson plan is going well. This is demonstrated by almost all teacher participants having the media of lesson plan. The availability of this learning media can be considered complete. These media are already owned by the teacher and have been used in the process of learning in the classroom. Learning media available and compiled by teachers who participated in the training include syllabus and lesson plan, annual program, semester program, mapping and assessment of competence standard and basic competencies, materials and analysis, as well as questions. This is in line with the provisions related to the completeness of the learning media.
Based on the results of research, the teachers who attend the training have been able to carry out their performance in the learning implementation. This can be seen from the indicators shown by the teachers which are 1) able to complete the task in accordance with the allocation of time subjects; 2) having adherence to the allocated time allocation; 3) initiating and terminating the learning program in accordance with the time allocation of the taught subjects; 4) having complete learning media that include evaluation tests, evaluation key answers, and assessment guidelines; 5) the beginning of the learning process with apperception; and 6) mastering the learning material and able to show it in the learning process.

According to Seels and Richey (1994), these processes are in line with the definition of AECT 1994 called the utilization area. Utilization is an activity using processes and resources to learn. Teachers involved in utilization have a responsibility to match the students with specific materials and activities, encourage the students to interact with selected materials and activities, guide the learning, and assess the results achieved, and incorporate them in continuation procedures.

In addition, facilities and infrastructure as the supporting tools for the success of a process have been utilized well by teachers. Hasbullah etal (2011) states that "the facilities of the schools have the important role to ensure quality of teaching and learning with respect to achieve quality of education. The performance of school facilities is significantly affected on student achievement". The statement implies that school facilities have an important role in ensuring the quality of teaching and learning processes related to the quality of education. The performance of school facilities significantly affects the students' achievement. This is in line with the statement by Lunenburg (2010) saying that that 'school buildings across the nation are aging and becoming a barrier to optimal learning and teaching" (less feasible buildings or facilities will hamper the optimal learning process). 
The last is about teacher performance in the learning evaluation. The assessment of student learning outcomes has been conducted by teachers who participate in the training at the end of learning material delivery. The goal is to assess the success or level of mastery shown by students in the learning process. The assessment techniques vary based on the material and competence that want to be achieved. This evaluation is conducted in the school as a material and psychosocial environment. The evaluation is carried out by bringing an assesment in concrete and complex situations. This evaluation is undergone by looking at all the learning elements as part of the whole system.

From that information, it is clear that the results of the learning assessment are useful to provide feedback for teachers as the effort to determine the level of implementation and achievement of the learning programs, encourage the students to increase the intensity and frequency of learning, and diagnose learning difficulties experienced by the students. Rosdiana (cited in Fitri, Saparahayuningsih, Agustriana, 2017) describes that the activities undertaken to end learning activities can be done in the form of summaries, conclusions, assessments, reflections, feedback, and follow-up.

Meanwhile, the document forms of student learning outcome obtained by the teacher who participate in the in-on service training of teacher competence improvement held by P2BKG Banten Province are the score list of student daily test, student personality book, and student portfolio report.

Teachers who participated in the training of learning evaluation can be considered succesful to be in the category "good". These results indicate that the teachers who participate in the training have performed quite well in the learning evaluation. The teachers have undertaken several activities in the learning evaluation phase, including 1) to be able to design and implement the learning evaluation with its essential indicators; 2) to design and conduct continuous evaluation of processes and learning outcomes with the use of various methods; 3) to analyze learning outcomes to determine mastery learning; 4) and to utilize the results of the learning assessment to improve the quality of the learning program in general. This is in accordance with the opinion of Triatna (2003) regarding the performance of teachers in the learning evaluation.

\section{Conclusion}

The characteristics of participants, trainer, and training organizers have supported the successful implementation of "in-on service training activities in improving teacher competencies held by P2BKG Banten Province". The training process has also been effective in terms of time, materials, performance of the trainer, use of media, and training environment that simultaneously give strong impact. The process of competence improvement conducted by the Teacher's Work Culture Development Program of Banten Province and other training institutions should be careful about the pedagogical performance and atmosphere; technical performance and atmosphere; sociological performance and atmosphere; participant activity during the program and technical atmosphere; participant activity during the program as well as psychological and social atmospheres of learning in the training. The atmosphere is a very strong influence on the effectiveness and success of learning in training.

Teachers who have already attended in-on service training on teacher competence improvement held by P2BKG Banten Province should be projected to become the core teachers in order to gain the opportunity to transfer their skills and expertise to other teachers both in MGMP and other activities in the neighborhood of the city / regency where they work. This program can be conducted through the Institution of Quality Assurance in Education as well as the Center for Development and Empowerment of Educators and Education Personnel. Teacher competence must be continuously developed along with the 
development of the era. It also needs support from various parties such as schools and government that continuously evaluate teacher performance on an ongoing basis. In addition, P2BKG can continuously innovate to create fun programs to support the teacher competence improvement.

\section{References}

[1] Anwar, K. (2014). Investasi Pendidikan: Suatu Fungsi untuk Pendidikan yang Bermutu, Jurnal Al-Fikrah: Jurnal Kependidikan Islam. Vol. 5, hlm. 1-10.

[2] Appleton, K. (2006). Science pedagogical content knowledge and elementary school teachers. In K. Appleton (Ed.), Elementary science teacher education: International perspectives on contemporary issues and practice (pp. 31-54). Mahwah, NJ: Lawrence Erlbaum Associates, Publishers.

[3] Aziz, A. (2015). Peningkatan Mutu Pendidikan. Pancawahana Jurnal Studi Islam. Vol. 10 No.2, p. 1-13.

[4] Baxter, J. A and Lederman, N. G. (1999). Assessment and measurement of pedagogical content knowledge. In J. Gess-Newsome \& N. G. Lederman (Eds.), Examining pedagogical content knowledge (pp.147-161). Dordrecht, The Netherlands: Kluwer.

[5] Chapman,J.D and Aspin,D.N. (1992). The School, The Community and Lifelong Learning, London: Cassell.

[6] Chukyoshin. (1996). First Report of 15th Session of the Central Council for Education: A tnodel for tlft nation's Education in the 21 st Century - Zest for Living and Peace of Mind. (Translation). Tokyo: Monbusho

[7] Clawson, J and Haskins, M. (2006). Teaching Management: A Field Guide for Professors, Consultants, and Corporate Trainers. (E-book). The Edinburgh Building UK: Cambridge University Press.

[8] Cochran, K. F., DeRuiter, J. A and King, R. A. (1993). Pedagogical content knowledge: An integrative model for teacher preparation. Journal of Teacher Education, 44, 263-272.

[9] Dessler, G. (1997). Manajemen sumber daya manusia. Jakarta: PT Prenhalindo

[10] DTK. (2008). Penilaian Kinerja Guru. Jakarta: Direktorat Tenaga Kependidikan, Dirjen PMPTK, Depdiknas.

[11] Ditjen PMPTK. (2010). Pembinaan dan Pengembangan Profesi Guru Buku 2: Pedoman Pelaksanaan Penilaian Kinerja Guru. Jakarta: Direktorat Jenderal PMPTK, Kemdiknas.

[12] Fauzi, I. (2011). Mengelola Pelatihan Partisipatif. Bandung : Alfabeta

[13] Fitri, Saparahayuningsih, and Agustriana. (2017). Perencanaan Pembelajaran Kurikulum 2013 Pendidikan Anak Usia Dini (Penelitian Deskriptif Kuantitatif Di Paud IT Auladuna Kota Bengkulu)

[14] Goh, P.S.C. (2013). Conceptions of Competency: A Phenomenographic Investigation of Beginning Teachers in Malaysia. The Qualitative Report 18(40), 1-16.

[15] Hardjana, A. (2009). Training SDM yang Efektif. Yogyakarta: Penerbit Kanisius.

[16] Hasbullah, A., Yusoff, W.Z.W., Ismail, M., et al. (2011). A framework study of school facilities performance in public primary school of Batubara district in Indonesia. Journal of Procedia Social and Behavioral Sciences, 15, 3708-3712.

[17] Hasibuan, J. (2012). Manajemen penyelenggaraan pendidikan dan pelatihan Balai Diklat Keagamaan Medan. Jurnal Tabularasa PPS Unimed, 9 (2), hlm. 215228.

[18] Imron, A. (1995). Pembinaan guru di Indonesia. Jakarta : PT. Dunia Pustaka Jaya

[19] Killen, R. (1998). Effective Teaching Strategies, Lessons from Research and Practice. Australia: Social Science Press.

[20] Loughran, J., Berry, A and Mulhall, P. (2006). Understanding and developing science teachers' pedagogical content 
knowledge. Rotterdam, The Netherlands: Sense Publishers.

[21] Lunenburg, F.C. (2010). School facilities management. National Forum of Educational Administration \& Supervision Journal. 27, 1-7

[22] Masnun, M. (2014). Strategi Peningkatan Kinerja Guru, Al-Ibtida: Jurnal Pendidikan Guru MI. Vol.1 No.2.

[23] Moleong, L. (2003). Metodologi penelitian kualitatif, Bandung, 2003, p.3.

[24] Musfah, J (2011). Peningkatan Kompetensi Guru: Melalui Pelatihan dan Sumber Belajar Teori dan Praktik. Jakarta: Prenada Media Group

[25] Partnership for 21st Century Skills, Framework for 21st Century Learning, http://www.p21.org/index.php?option=co m_content $\&$ task $=$ view $\&$ id $=254 \&$ Itemid $=1$ 20 [Accessed on 11-1-2016].

[26] Risnawatiririn. (2009). Konsep Kinerja Guru. Yogyakarta : UPP STIM YKPN

[27] Seels, B and Richey, R. (1994). Instructional Technology: Definition and Domain of Field. Washington DC Association for Educational

[28] Sudaryanto. (2016). Pendekatan prinsip adult learning dalam upaya menunjang proses pembelajaran diklat aparatur. Forum Diklat, 2 (2), 65-73.

[29] Schwarz, R. (2002). The Skilled Facilitator: A Comprehensive Resource for Consultants, Facilitators, Managers, Trainers, and Coaches. San Frasisco: Jossey-Bass.

[30] Sudaryanto, D. (2016). Pendekatan prinsip adult learning dalam upaya menunjang proses pembelajaran diklat aparatur. Forum Diklat, 2 (2), p. 65-73.

[31] Tamim. D dan Hermansjah. (2002) Diklat Sebagai Suatu Sistem. Jakarta: Lembaga. Administrasi Negara.

[32] Triatna, C. (2007) Evaluasi Kinerja Guru dan Upaya Penjaminan Mutu Sekolah. Jurnal Administrasi Pendidikan, Vol.V, No.II, April 2007, 51-66.
[33] Thijs, A, Jenne van der Velde, Stephan Meershoek, Suzan van Dieren and Elvira Arkesteijn (2011) Quality framework for UNESCO schools. Enschede The Netherlands: Netherlands institute for curriculum development, Enschede, 2011, p. $9-10$.

[34] Tjutju dan Suwatno. (2011). Manfaat dan Tujuan Penilaian Kinerja Guru. Jakarta : Rineka Cipta

[35] Usman and Uzer, M. (1950). Menjadi guru profesional. Bandung: PT. Remaja Rosdakarya

[36] Widodo, A. (2017). Teacher Pedagogical Content Knowledge (PCK) and Students' Reasoning and Wellbeing. Journal of Physics: Conference Series. Ser.812. 1-7

[37] Ycc. A. H. (1989) Cross-cultural Perspectives on Higher Education in East Asia: Psychological effects upon Asian students. Journal nf Multilingual and Multicultural Development, 10 (3), 213232. 